\title{
対称倸留系における船舶の動摇と船舶係留誘導装置 に作用する接岸力
}

\author{
上田 茂*. 白石 悟**. 板生考司***
}

\section{1. まえがき}

本研究では, 港湾にお牧る船船の係留および荷役の稼 働率を向上させる目的で, 対称係留系および船舶係留誘 導装置を提案し, 計算および実験を行ってその有効性を 検討した（上田他，1992）.

港湾の施設の技術上の基準 - 同 解 説 (1989a)（以下, 技術基準）では，泊地での荷役限界波高（有義波高）は 対象船舶の船種, 船型, 荷役方法によっても異なるが, 小型船, 中・大型船, 超大型船において, それぞれ, $0.3 \mathrm{~m}, 0.5 \mathrm{~m}, 0.7 \sim 1.5 \mathrm{~m}$ 程度とされている. 所要の 静穏度を確保するために, 防波堤および消波工の配置お よび設計が適切になされているが，これに加えて係留施 設を改善し, 稼働率を一層向上させることが望まれる. たとえば，全天候バースは，防風設備执よび締切堤によ ってバース外の強風抢よび波浪の影響を抑光，荷役の稼 働率を向上させるものである. また, 開発中のスーパー ライナーは高速で航行するものであるので, 係留施設に おいても迅速な離着栈拉よび高能率の荷役が要請され る.一方, 離島等の外洋性港湾では, 防波堤等の整備が 十分でなく，現実には荷役限界波高を満たす静穏度が得 られていないことが多い.

通常の係留系, すなわら, 係船岸の防衝工と船船の係 留索による係留系（これを非対称係留系とする）に掠け る問題点は，防䑪材と係留索のばね定数の差異が大きい ので，これが原因となって係留船舶がサブハーモニック モーションを起こすことである. そこで，これを抑制す るために船舶の両舷側に防衝工および係留索を配置し て, 船舶の前後または左右の係留系の変位復元力特性を 同一にする対称係留系を考えた．対称係留系に拈いては 両側に配置する係留施設による消波効果も期待できる.

船舶係留誘導装置に類似なものとして, 久保他 (1990) は荒天時に漁船が避難して漁港に入港する際に, 風の作 用によって漁船が漂流するのを防止するための入港援助

\footnotetext{
$*$ 正会員 工博 運輸省港湾技術研究所構造部

**正会員 運輸省港湾技術研究所構造部 $* * *$

運輸省港湾技術研究所構造部（現第五港湾建設局四 日市港工事事務所）
}

施設を提案し, 漁船の衝突力を実験的に調べ, 防衝工の 構造を検討している. 船舶係留誘導装置の検討に当たっ ては, 船船が船舶係留誘導装置に接舫するときの接岸力 を明らかにしなければならない。

\section{2. 模型実験の概要}

\section{1 実験施設および模型}

a）模型および実験水槽

模型船船の接岸実験および動摇実験は港湾技術研究所 の平面水槽 $(25 \mathrm{~m} \times 10 \mathrm{~m} \times 1 \mathrm{~m})$ に和いて行った. 表一 1 は, 模型船舶および実船の諸元を示したものである. 模型船船は，10,000 DWT 程度の旅客船の $1 / 75$ 縮尺の ものである. 模型船船はバッテリーおよびモーターを搭 載しており，リモコンによってスクリュ一の回転数およ び舵角を操作し前後左右に航行させることができる。

図一1 は,アクリル製の係留施設模型を示したもの で, 模型は合計 9 ユニットで構成される. 各ニニットの 長さ, 幅, 高さは $1.0 \mathrm{~m} \times 0.4 \mathrm{~m} \times 0.31 \mathrm{~m}$ である. ユニ ット 1〜 4 および 7,8 には，防舷材模型が 2 個づつ取り

\begin{tabular}{|c|c|c|}
\hline 表一-1 & \multicolumn{2}{|c|}{$\begin{array}{l}\text { 模型船舶抢よび } \\
\text { 実船の諸元 }\end{array}$} \\
\hline 諸元 & 模型船 & 実船 \\
\hline 全長 & $146.5 \mathrm{~cm}$ & $102.6 \mathrm{~m}$ \\
\hline 垂線間長 & $135.0 \mathrm{~cm}$ & $101.3 \mathrm{~m}$ \\
\hline 型深さ & $14.0 \mathrm{~cm}$ & $10.5 \mathrm{~m}$ \\
\hline 型幅 & $20.2 \mathrm{~cm}$ & $15.2 \mathrm{~m}$ \\
\hline 喫水 & $12.3 \mathrm{~cm}$ & $9.2 \mathrm{~m}$ \\
\hline 排水量 & $26.3 \mathrm{~kg}$ & $11000 t$ \\
\hline
\end{tabular}

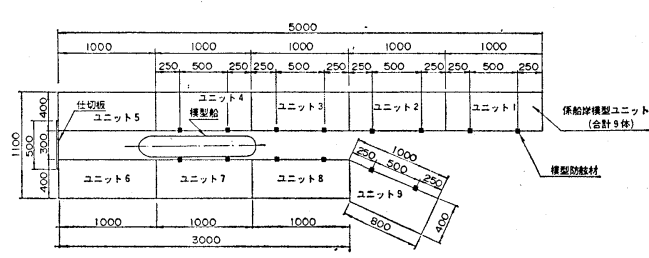

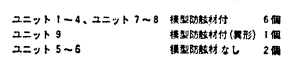
図一1 係留施設模型 
付けられている.ニニット9は, 船船が入港しやすいよ らに $30^{\circ}$ の角度に配置されている. 模型の前面取付板 は, 着脱が可能である. 前面取付板を取付けた時にはケ ーソン倸船岸の様な非透過性の係留施設に相当し, 取り はずした時には栈橋の様な透過性の係留施設に相当す る. 透過性および非透過性の係留施設とは別に, ニニッ ト 6〜9の前面取付板を取りはずし, この面が透過性 で, ニニット 1〜 5 の面が非透過性の係留施設を考えた. 以上の 3 種類の係船岸をそれぞれ, 壁面両側非透過（以 下, 両側非透過), 壁面両側透過 (以下, 両側透過), 壁 面片側透過・片側非透過（以下，片側透過）とする.

\section{b）防衝工}

船舦が船舶係留誘導装置に沿って入港する際には, 防 衙工に圧縮とせ九断を与えながら入港する. 本研究に打 いては，係船岸法線方向の接岸力のみを検出することと し, 船舶係留誘導装置の模型の前面にベアリングを取り 付け, 前進速度拉よびサージ，ヒーブによる前後抢よび 上下のせん断力を軽減し, 係船岸の法線に直角方向の接 岸力のみを防衝工に伝えるようにした。

防舷材は実際の係船岸に新いて，ばね定数がおよそ $240 \mathrm{tf} / \mathrm{m}$ (模型換算 $0.42 \mathrm{kgf} / \mathrm{cm}$ ) 相当のものが 1 二 ット当り15個設置されているものとする. 防舷材 1 個の 模型換算のば祮定数が極めて小さいために，模型製作が 困難であったので，1ユニット当たりの合計のばね定数 を2 個の模型防舷材で代表させた.すすなわち, 模型防舷 材のばね定数は $3.16 \mathrm{kgf} / \mathrm{cm}$ (実機換算 $1,778 \mathrm{tf} / \mathrm{m}$ ) で ある.

\section{c) 係留索}

模型係留索はワイヤにコイルスプリングを取り付けた ものとした. ワイヤはコイルスプリングに較べて充分に 硬く伸び率が小さいので, 係留索の伸びはコイルスプリ ングの伸びと同一とみなせる．実機で $\phi 50 \mathrm{~mm}$ ，長さ $40 \mathrm{~m}$ のナイロンロープを使用するものとして, 新品口 ープの変位復元力特性の原点と切断荷重の $1 / 3.8$ 亿対す る点とを結んだ平均ば权定数をもって係留索のばね定数 とした、模型係留索のばね定数は $7.14 \mathrm{gf} / \mathrm{cm}$ (実 機 換 算 $4.02 \mathrm{tf} / \mathrm{m}$ ) である.

\section{2 接岸実験の方法と実験ヶース}

\section{a）接岸実験の方法}

接岸実験は静水中と波浪中において, 前進速度をもつ 場合抢よびもたない場合のそれぞれについて行った。

接岸速度は, 船船が接岸する時の嗃度 $V$ を係船岸法線 方向の成分 $V_{x}$ ととれに直交する成分 $V_{y}$ に分けた時の $V_{y}$ をいう. $V_{y}$ は船船の接岸直前の速度 $V$ と係船岸法 線に対する角度 $\theta$ を測定して, 式 (1) で求めた.

$$
V_{y}=V \times \sin \theta
$$

ここに, $V:$ 船舶の速度 $(\mathrm{cm} / \mathrm{s})$, ビデオカメラによっ
て撮影し、コマ送りをして模型船舶のマーク点を読み取 り解析した速度, $\theta$ : 船舶の接岸角度 (deg) である.

通常, 船舶は波高 $0.5 \sim 0.7 \mathrm{~m}$ 飞颃いて $0.3 \mathrm{~m} / \mathrm{s}$ 以下 の速度で接岸する.この接岸速度を模型換算すると 3.46 $\mathrm{cm} / \mathrm{s}$ である. 船船係留誘導装置に作用する接岸力の模 型実験では，港口部の波浪条件を $2 \sim 3 \mathrm{~m}$ と想定してい るので操船に困難さが伴い，接岸速度が $3.46 \mathrm{~cm} / \mathrm{s}$ を超 えることが予想されるので，これをやや上回る接岸速度 を目標に実験を行った。また，接岸角度を变えて実験を 行った.

b）測定項目および実験ヶース

接岸実験に抢いては模型防舷材の荷重計によって防衝 工の反力を測定した。また，容量式波高計を用いて波高 および周期を測定した．さらに，ビデオカメラを使用 し, 模型船舶が前面受圧板と接触した時の, 接岸速度, 接岸速度の方向と係船岸法線 とのなす角度, 船体と係船 岸法線とのなす角度, 船体が前面受圧板と接した位置と 防衝工までの距離を測定した。接岸実験は静水中と波浪 中において行った．波浪中接岸実験は不規則波中で，波 向は $0^{\circ}$ および $30^{\circ}$ の 2 種類, 有義波高は $1.0 \sim 2.67$ $\mathrm{cm}$ の 5 種類, 有義波周期は $0.577 \sim 1.732 \mathrm{~s}$ の 5 種類に ついて行った.これらを実機換算すると, 有義波高は $0.75 \sim 2.0 \mathrm{~m}$ ，有義波周期は 5 15 s である. 接岸実験 は，静水中に执いては50回，波浪中に执いては各波浪条 件毎に10回行った.

\section{3 動摇実験の模型と実験ヶース}

a) 動摇実験の模型

図一2 は対称係留系における防衝工と係留索の配置を 示したものである. 非対称係留系は対称係留系と同一の 防衝工および係留索が片側のみについているものとす る. 後述する計算結果からみて, 非対称係留系に比べ対 称係留系が有利であるので, 動摇実験は対称係留系につ いてのみ行った.

b）測定項目および実験ケース

動摇実験に执いては防衝工の反力, 係留索の張力, 波 高, 周期を測定する、また， 6 自由度計を用いて船船の 動摇 6 成分を測定する. 波浪条件は接岸実験と同様に, 不規則波について波向 2 種類, 有義波高 5 種類, 有義波 周期 5 種類である.

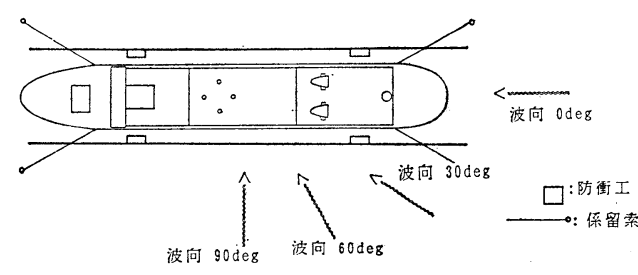

図一2 対称係留系における防衝工と係留索の配置 


\section{3. 船舶係留誘導装置に作用する接岸力の 実験 結果}

\section{1 静水中の接岸力}

a） 実験結果の整理の方法

技術基準に基づいて，船船の接岸エネルギーを式 (2) によって計算する (上田, 1981; 日本港湾協会, 1989b).

$$
E_{f}=\frac{W_{s} \cdot V_{y}^{2}}{2 g} \times C_{e} \times C_{m} \times C_{s} \times C_{o}
$$

ここに, $E_{f}:$ 船舶の接岸エネルギー $(\mathrm{tf} \cdot \mathrm{m}), g:$ 重力加 速度 $\left(9.8 \mathrm{~m} / \mathrm{s}^{2}\right), W_{s}$ : 船船の排水量 $(0.0263 \mathrm{t}$, 模型 船舶の重量), $V_{y}$ : 船舶の接岸速度（法線に直交する方 向成分, $\mathrm{m} / \mathrm{s}), C_{e}$ : 偏心係数, $C_{m}$ : 仮想質量係数, $C_{s}$ : 柔軟性係数, $C_{e}$ : バースの形状係数である.

仮想質量俰数 $C_{m}$ は 1.8 として計算し, 実駼值と比較 した. この洼か柔軟性係数 $C_{s}$ およびバースの形状係数 $C_{c}$ は 1.0 とした。

b) 実験結果

図一3（1）拈よび (2) は静水中に打沙前進速度をる つ場合ともたない場合の接岸力の実験結果である. 図の 横軸は接岸速度 $V y$, 縦軸は接岸力 $P$ である. また，図 -4（1）打よび（2）は，前進速度をもつ場合之もたない 場合の接岸力の計算結果である. 船船係留誘導装置作 用する接岸力は, 前進速度の有無にかかわらず計算値と 実験值の上限がほぼ一致して括り，接岸力は係船岸の法 線に直角方向の速度成分 $V y$ を接岸速度として，技術基 準の方法に従って計算してよいと言える，ただし，接岸 速度が $4 \mathrm{~cm} / \mathrm{s}$ を超えるときには接岸力の実験值は接岸
速度に比例せず，接岸力は 1 1.2 kgf とほぼ一定值に なっている.この原因は明確ではないが荷重計の性能に 起因すると考光られる.

\section{2 波浪中の接岸力}

有義波高，有義波周期打よび波向を变光て接岸実験を 行い，波浪条件が接岸力へ及将す影響を調べた。图一5 は，波向 $0^{\circ}$ ，有義波高 $2.0 \mathrm{~cm}$ で，有義波周期 $1.732 \mathrm{~s}$ の場合の実験結果を示したものである。なお，図の上部 に示した数值は最小自乗法によって求めた回帰式の勾配 であるが，ここには図示していない有義波周期 $0.577 \mathrm{~s}$ ， $0.805 \mathrm{~s}, 1.115 \mathrm{~s}, 1.386 \mathrm{~s}$ の場合を含めてその值を示す と，有義波高 $1.0 \mathrm{~cm}$ の場合に性に，0.185，0.182， $0.199,0.205,0.215 \mathrm{kgf} /(\mathrm{cm} / \mathrm{s})$ ， また，有義波高 2.0 $\mathrm{cm}$ の場合には順に，0.273，0.230,0.218, 0,201, 0.268 $\mathrm{kgf} /(\mathrm{cm} / \mathrm{s})$ となって，長周期波中纱よび波高が大きい ときに接岸力が大きいことがわかる。波浪中の接岸実験 結果と図一 4 に示した静水中の接岸力の計算値とを比較 すると，長周期波中では静水中よりも接岸力が大きい。 これらの現象は船舶の動摇に起因すると言える.

\section{4. 対称係留系における動摇実験の結果}

\section{1 自间振動実験}

実験水槽に私いて模型船船のロールの自由振動実験を 行い減衰定数 $h$ 扝よび固有周期を求めた。模型船船の口 一ルの固有周期は $2.18 \mathrm{~s}$, 減衰定数は 0.14 である. 計 算では，渦の発生によるロールの減衰力を評価できない ので， 5.に示寸数値シミュレーションに执いては自由振 動実験によって得られたロールの減衰定数を用いる.

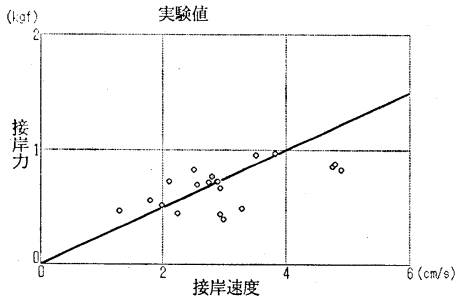

（1）前進速度をもつ接岸

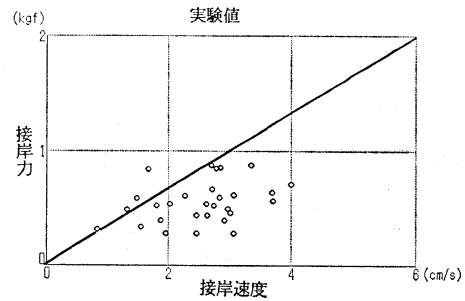

（2）前進速度をもたない接岸 図一3 静水中接岸実験の接岸力と接岸速度（実験値）

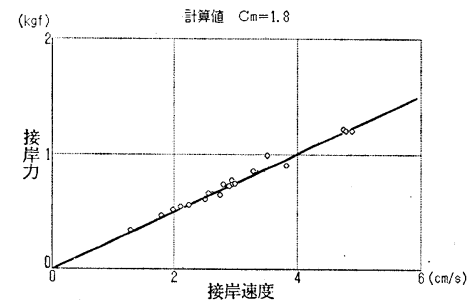

(1) 前進速度をもつ接岸

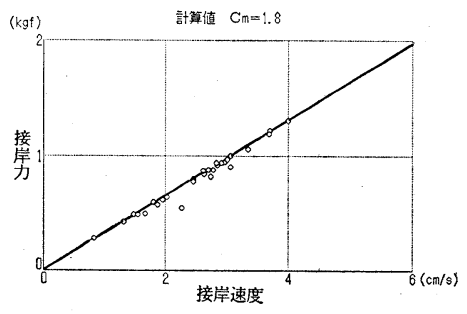

（2）前進速度をもたない接岸 図一4 静水中接岸の接岸力と接岸速度（計算値）

\section{2 係船岸の壁面の構造と動摇量 の相違}

図一6 特よび図一7 は，対称係留系 に抢いて係船岸の壁面の構造を両側非 透過，片側透過，両側透過として，動 摇の両振幅の有義値と有義波周期の関 係を示したものである，ただし，波向 $30^{\circ}$ ，有義波高 $1.5 \mathrm{~m}$ の実験ヶースに ついて比較する. 図面の数值はすべて 実機換算値である。

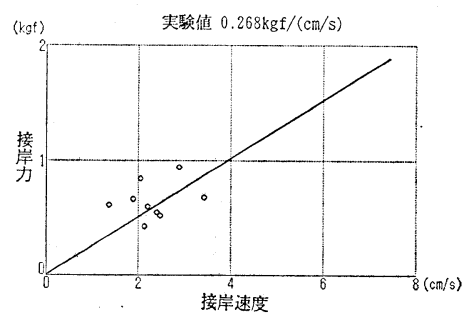

図一5 波浪中接岸実験の接岸力と接 岸速度 
図一6 はスウェイの有義両振幅を示すが，片側透過拉 上び両側透過の場合には両側非透過の場合に比べてスウ ェイの動摇が著しく大きい，両側非透過の場合は波が回 折して船舶に対する作用角度が注济 $0^{\circ}$ に近いのに対し て，片側透過衿よび両側透過については $30^{\circ}$ の波が直接 作用してくるので動摇量が大きい. しかも，片側透過の 場合には両側透過比比係船岸前面の反射波が加わるの で, 3 形式のうちでは最も動摇振幅が大きい.な拉，こ こには図示していないが，ロール，ヨウについてもスウ エイとほ涪同様な傾向がみられる.

図一7 はサージの有義両振幅を示すが，両側透過の場 合が他の構造礿式のものより小さい，係船岸の構造を透 過性にすることによってサージの動摇量が小さくなる が，図一6に示したようにスウェイの動摇両振幅が大き くなっている、また，離島等では，防波堤の片側を係船 岸として利用することが多いので，一方が非透過の状態 である、したがって，両側透過という構造は現実的では ない，そこで，サージの動摇両振幅を小さくするには， 非透過性係船岸の反射波を小さくして, 防波堤や係船岸 に沿って入ってくる波を抑光るのがよいといえる。な お，ここには図示してい灾いが，ヒーブ，ト゚ッチについ てもサージと注涪同様な傾向がみられる.

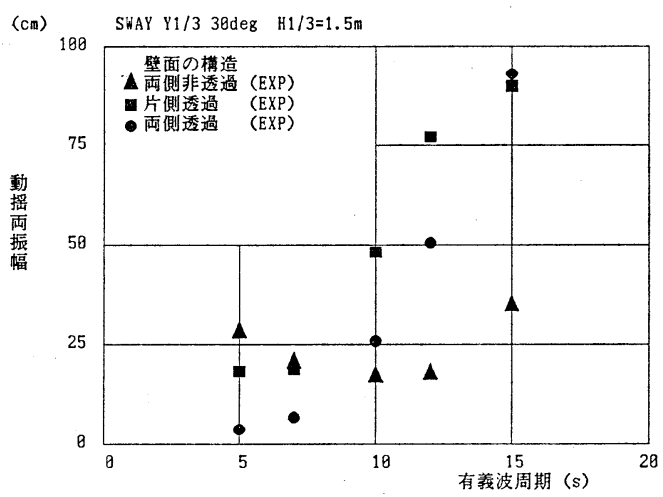

図一6壁面の構造による動摇両振幅の差異（スウェイ）

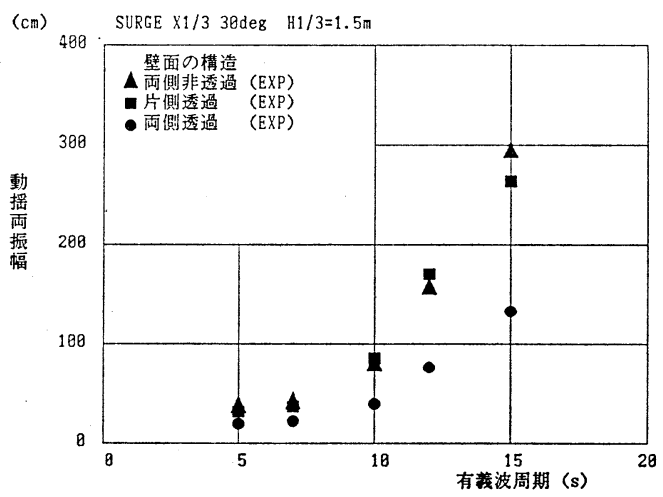

図一7壁面の構造による動摇両振幅の差異（サージ）

\section{5. 動摇シミュレーションによる検討}

\section{1 検討の手順}

模型船舶の実機諸元について港湾技術研究所で開発し た係留船舶の動摇計算プログラム（上田，1984）を用い て動摇シミュレーションを行った．計算に就いては波漂 流力および流れによる力は微小であるとして無視する. また，防䑪材抢よび係留索の変位復元力特性をモデル化 し, 動摇シミュレーションに入力した.

\section{2 計算值と実験值との比較}

図一8 抢よび図一9 は波向 $30^{\circ}$, 有義波高 $1.0 \mathrm{~m}$ で片 側透過拉よび両側透過のときのサージ括よびヒーブの計 算値と実験值について, 動摇両振幅の有義値を示したも のである.

図一8 はサージの動摇両振幅について実験値と計算値 とを比較したものである.片側䢪過の場合には実験值と

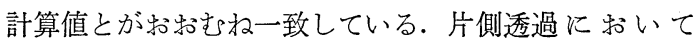
は，非透過性係船岸による反射波と透過性係船岸の脚に よる波の干渉が係留船船の動摇に影響を及ぼすが，前者 の影響の方が大きい，したがって，計算では透過性係船 崖の脚に上る波の干渉は考虑していない子のの, 実駼值 と計算值とが抢招む权一致している，両側透過の場合に

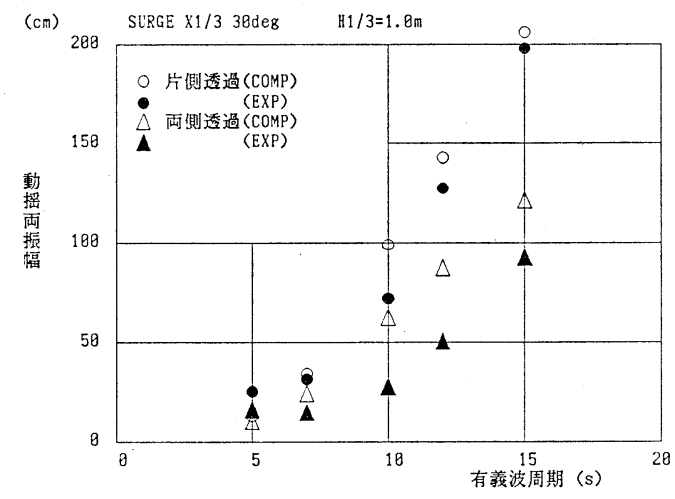

図一8 サージの実験値と計算值の比較

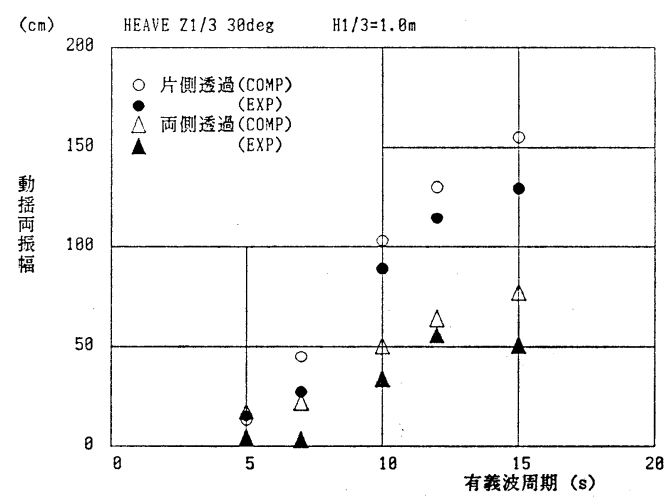

図一9 ヒーブの実験值と計算値の比較 


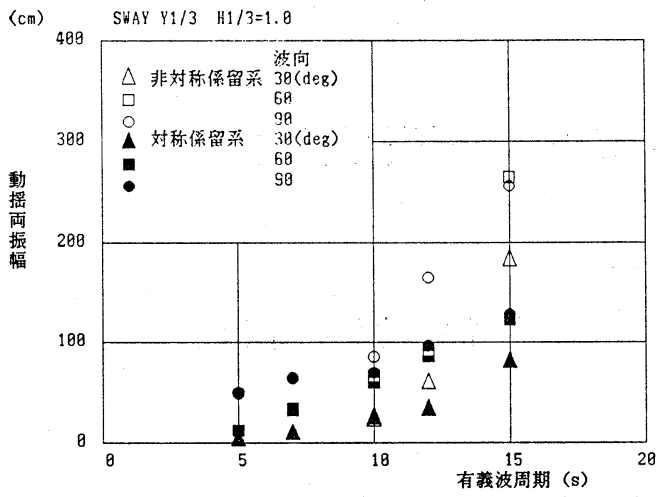

図一10 対称係留系と非対称係留系による動摇の差異

は波周期が長いところで実験值に比べて計算值が大きく なる. 実験では両側の壁面が完全に透過ではなく，模型 係留施設の脚の部分の消波効果による波高の減少がある ためでめると考光られる。

図一9 はヒーブの動摇両振幅とついて実験值と計算値 とを比較したものである.片側透過の場合には実験值と 計算值とが招拈む敉一致している。両側透過の場合に は, 実験値と計算值とを比較すると，全体的に実験值に 比べて計算值が大きくなる。これは先にも述べたよう に，模型係留施設の脚の部分の消波効果による波高の減 少によるものと考光られる.

なお，ここには四示していないが，ロール，ピッチ， ヨウは実験值と計算值とが招招む致している。しか しながら，スウェイについては実験值と計算値とではや や相違があった.

\section{3 対称係留系と非対称係留系との比較}

図一10は対称係留系拉よび非対称係留系で波向 $30^{\circ}$, $60^{\circ}$ 抽よび $90^{\circ}$ で有義波高 $1.0 \mathrm{~m}$ のときのスウェイの両 振幅の有義值と有義波周期とり関係を眓示したものであ る. 対称係留系および非対称保留系のいずれについても 有義波周期が長くなると動摇両振幅が大きくなる傾向に あるが，有義波周期 $10 \mathrm{~s}$ を超兄ると対称係留系に比べ非 対称係留系の方が波周期の影響が大きく動摇量が增大す る.

なお，ここには図示していないが，サージ，ロール， ヨウについても対称係留系の動摇両振幅が非対称係留系 の動摇両振幅よりる小さい.ただし，ヒーブ, ピッチに ついては倸留系の影響が小さいので両係留系による動摇 両振幅の差異はない。

\section{6. 結 論}

1）船舶係留誘導装置に作用する接岸力は, 前進速度
をもつ接岸の場合も前進速度をもたない接岸の場合も計 算值と実験值が注ぼ一致して战り, 接岸力は係船岸の法 線に直角方向の速度成分 $V_{y}$ を接岸速度とし，これをも って技術基準の方法に従って計算してよいといえる。

2）波浪中に执いては長周期波中または波高が大きい ときには船船の動摇が大きいために, 接岸力は静水中よ りも大きいので，設計上留意する必要がある.

3）対称係留系と非対称係留系について動摇シミュレ ーション計算を行った結果を比較すると, 対称係留系に おいてはサブハーモニックモーションが抑制されるた め, サージ, スウェイ, ロール, ヨウについて, 非対称 係留系より係留船船の動摇が小さい.

4）対称倸留系に执いて, 係船岸の構造を, 両側非透 過, 片側透過, 両側透過として, それらの動摇量を比較 してみると, スウェイ、ロール，ヨウについては両側非 透過が，またサージ，ヒーブ，ピッチについては両側透 過の動摇量が他の形式のものよりも小さい.

5）係留船舶の動摇シミュレーション結果は実験結果 と打招むね一致した。

\section{7. あとがき}

本研究は港湾施設の係留抒よび荷役の稼働率の向上を 目的として, 係留船船の動摇特性に着目して船船の動摇 を抑制する係留システムを提案し，係留船船の動摇を模 型実験抢よび動摇シミュレーションによって検討した. また，このシステムを利用するに当たり入港時の操船の 困難さを解消するための船舶係留誘導装置に作用する接 岸力を実験により求めた. 対称係留系は係留船舶の動摇 を低減する効果があることが確認され，この施設の有効 性が確認された，対称係留系拉よび船舶係留誘導装置は 全天候バース，スーパーライナー用バース，離島等の外 洋性港湾などに括汀る活用が期待される.

\section{参 考 文 献}

上田 茂 (1981)：大型タンカーの接岸力に関する研究，港湾技 術研究所報告, 第 20 巻, 第 2 号, pp. 168-209.

上田 茂 (1984)：係留船舶の動摇解析手法之その応用に関する 研究, 港湾技研資料, No. $504,372 \mathrm{p}$.

上田 茂・白石 悟・板生考司 (1992)：対称係留系似引打船 船の動摇と船舶係留諗導装置儿作用する接岸力, 港湾技研 資料，No. $730 ， 42 \mathrm{p}$.

久保雅義・斎藤勝彦・大音宗昭 (1990)：漁船の入港援助施設に 関する基礎的研究, 海岸工学論文集, 第 37 巻, pp. 728-732.

日本港湾協会 $(1989 \mathrm{a})$ ： 港湾の施設の技術上の基準・同解説, 下巻, p. 12.

日本港湾協会 (1989b)：港湾の施設の技術上の基準・同解説， 上巻, pp. 17-20. 